\title{
Desain Power Sistem PV pada DC Microgrid berdasarkan Kombinasi Supercapacitor dan
}

\author{
Battery
}

\author{
Machmud Effendy $^{1}$, Rizky Dwiki Zulyazis ${ }^{2}$, Nuralif Mardiyah ${ }^{3}$ \\ ${ }^{1,2,3}$ Teknik Elektro Universitas Muhammadiyah Malang \\ Jl. Raya Tlogomas 246 Malang 65144 \\ e-mail: machmud@umm.ac.id
}

\begin{abstract}
Abstrak - Baterai dan superkapasitor memiliki karakteristik yang berbeda sehingga sebuah sistem penyimpanan sangat sulit di injeksikan ke sebuah jaringan transmisi (grid) yang akan langsung dihubungkan dengan daya permintaan (Load Demand). Dc Microgrid adalah solusi utama yang mana sumber energi berasal dari Photovoltaic dan storage system berasal dari kombinasi Battery dan Supercapacitors. Penggunaan kombinasi Supercapacitors dan Battery berfungsi untuk mengurangi kinerja baterai yang berlebih. Power Management Strategy digunakan untuk menentukan seberapa besar daya yang dibutuhkan pada grafik daya permintaan, Kontrol Logika Fuzzy digunakan sebagai kontrol utama pada sistem ini untuk menentukan refrensi masukan pada Supercapacitors. Hasil simulasi menunjukan Supercapacitors mampu mensuplai kekurangan energi pada baterai dengan waktu lebih singkat.
\end{abstract}

Kata kunci: Dc Microgrid, Photovoltaic, Power Management Strategy, Supercapacitors, Fuzzy

\begin{abstract}
Batteries and super capacitors have different characteristics so that a storage system is very difficult to inject into a transmission network (grid) which will be directly connected to the demand power. Dc Micro grid is the main solution where energy sources from Photovoltaic and storage systems come from a combination of Battery and Super capacitors. The use of a combination of Super capacitors and Battery serves to reduce the performance of excessive batteries. Power Management Strategy is used to determine how much power is needed in the demand power graph, Fuzzy Logic Control is used as the main control in this system to determine the reference input to Supercapacitors. The simulation results show that super capacitors are able to supply a lack of energy in batteries with a shorter time.
\end{abstract}

\section{Keywords: Dc Microgrid, Photovoltaic, Power Management Strategy, Supercapacitors, Fuzzy}

\section{PENDAHULUAN}

Karakteristik pada baterai dan superkapasitor (SC) yang berbeda membuat sebuah sistem penyimpanan akan sangat sulit sekali di injeksikan ke sebuah jaringan transmisi (grid) yang akan langsung berhadapan dengan daya permintaan (Load Demand). Perbedaan keluaran tegangan yang membuat sebuah sistem akan mengalami kesulitan pada saat terjadi lonjakan daya permintaan, maka dari itu diperlukan Power Management Strategy sebagai pengontrol keluaran tegangan yang ada pada sistem penyimpanan agar kombinasi baterai dan superkapasitor dapat memenuhi daya permintaan.

Jaringan transmisi Mikro Arus Searah (DC Microgrid) dapat menjadi solusi karena sumber energi berasal dari energi terbaharukan berupa Photovoltaic (PV) yang mana karakteristik PV diperlukan agar sebuah sistem Microgrid bekerja secara maksimal dan sesuai kebutuhan. Dalam era terbaru ini sebuah jaringan listrik mudah dikendalikan dan juga lebih efisien dan ekonomis dari segi instalasi pemasangan dan pemanfaatan energi. Dimana semakin berkurangnya sumber daya fosil sebagai bahan bakar utama pembangkitan listrik di dunia, maka penggunaan sumber daya fosil semakin berkurang dan beralih menggunakan sumber daya terbaharukan (Renewable Energy). Sebuah jaringan transmisi Mikro Arus Searah (DC Microgrid) dapat menjadi solusi karena system ini terdiri dari sumber energi terbarukan dimana sumber energi dan penyimpanan energi saling terhubung untuk memenuhi permintaan daya beban setiap saat [1].

Jaringan transmisi DC mempunyai efisiensi tinggi karena memiliki faktor daya $=1$, sehingga rugi - rugi daya pada sistem dioperasikan dapat berkurang, dan juga dapat mengurangi besarnya nilai tegangan jatuh yang ditimbulkan pada saat transmisi energi listrik. Sistim ini juga tidak memiliki masalah terhadap stabilitas sistem sehingga memungkinkan untuk penyaluran jarak jauh serta memiliki isolasi yang lebih sederhana ekonomis dan efisien.

Jaringan DC Microgrid bertujuan untuk mengihindari fluktuasi tegangan jaringan, atau bahkan pemadaman listrik setiap saat. Jaringan listrik harus menyeimbangkan kekuatan antara produksi dan konsumsi dengan margin 
kesalahan kecil [2]. DC Microgrid sangat berguna karena merupakan bagian dari sebuah sistem utama yang memiliki keunggulan pengaturan terhadap jaringan dirinya sendiri, sehingga jika terjadi gangguan terhadap sistem jaringannya dapat diatasi dan masih dapat menjalankan fungsi pembangkitan dan penyaluran sendiri untuk memenuhi beban yang dibutuhkan untuk menggantikan jaringan listrik utama. Sumber daya yang digunakan pada jaringan DC Microgrid yaitu photovoltaic. Photovoltaic atau solar cell adalah teknologi yang ramah terhadap lingkungan dan tidak menghasilkan kebisingan dan effisiensi yang tinggi [3]. Untuk Memaksimalkan produksi energi pada PV, metode MPPT dibutuhkan untuk mempertahankan puncak energi pada PV [3]. Supercapacitor (SC) biasa digunakan sebagai penyangga kebutuhan tenaga dalam jangka pendek atau sebagai energi cadangan pada energi terbarukan. Kombinasi baterai dan superkapasitor akan meningkatkan kinerja baterai dari sistem dan daya tahan baterai [4].

Jaringan DC Microgrid yang berbasis pada sumber energi photovoltaic, dengan kombinasi Superkapasitor dan baterai sebagai storage system adalah sebuah sistem jaringan transmisi mandiri. Algoritma berbasis logika fuzzy digunakan untuk memecahkan masalah manajemen energi dan distribusi energi antara baterai dan SC. Namun, penggunaan logika fuzzy tidak memerlukan model matematika yang kompleks seperti yang digunakan dalam system kontrol klasik [5]. Fungsi Fuzzy Logic Controller adalah sebagai back up system ketika terjadi kekurangan daya energy berdasarkan SoC pada baterai. Setiap elemen yang terpasang / terhubung ke jaringan DC bus memiliki konverternya masing - masing.

Setiap elemen yang terhubung pada jaringan DC Microgrid memiliki masing - masing karakteristik yang berbeda sehingga Power Management System dirancang berdasarkan karakteristik yang berbeda - beda dari superkapasitor dan baterai" [6]. Pengaturan daya masukan dan keluaran pada setiap elemen diatur pada bagian blok yang berbeda yang mana pada bagian sistem ini untuk mengetahui energi suatu sistem yang dihasilkan pada setiap elemen menggunakan Manajemen Energi (Power Management System). [7-9]

\section{METODOLOGI}

Gambar 1 menunjukkan blok diagram sistem jaringan DC Microgrid, yang terdiri dari PV, boost converter, buck-boost converter, baterai, superkapasitor, sistem power management, dan beban

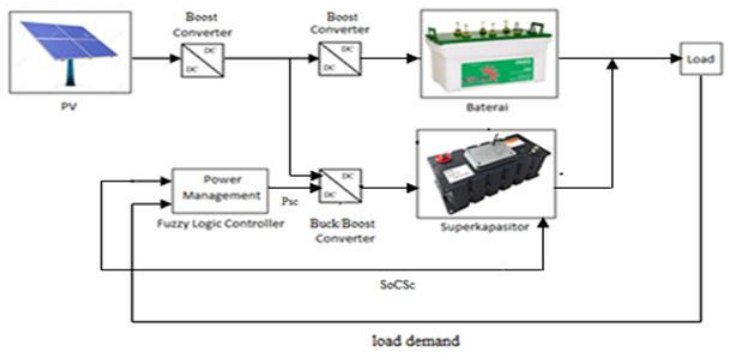

Gambar 1. Konfigurasi Jaringan DC Microgrid

\section{A. Boost Converter}

Boost converter adalah converter yang bekerja sebagai penaik tegangan DC. konverter ini merupakan bentuk dari sebuah power-supply yang dibutuhkan ketika sebuah nilai tegangan pada rangkaian elektronika lebih rendah dari tegangan supply maka fungsi konverter tersebut sebagai penaikan tegangan..

Untuk menentukan nilai duty cycle digunakan rumus pada persamaan $1[10,11]$.

$D_{\text {boost }}=1-\frac{V_{s}}{V_{0}}$

Setelah menentukan nilai duty cycle maka selanjutnya dapat menentukan nilai induktor.

$$
L m i n=\frac{(1-D)^{2} * D * R}{2 * f}
$$

Selanjutnya adalah menentukan nilai kapasitor dengan menggunakan Persamaan 3.

$$
C m i n=\frac{D * V o w t}{V r * R * f}
$$

Rangkaian boost converter ditunjukkan pada gambar 2 .

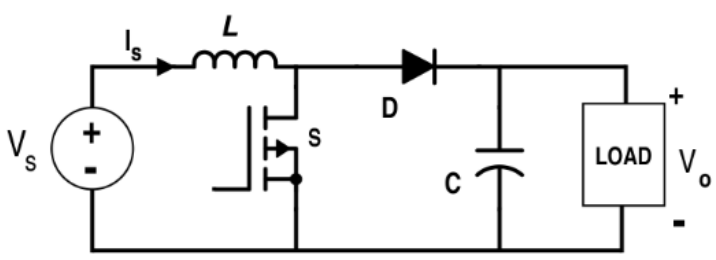

Gambar 2. Rangkaian Boost Converter

\section{B. Buck-boost Converter}

Buck-Boost converter adalah rangkaian yang berfungsi untuk menaikan dan menurunkan tegangan, pada bagian buck berfungsi untuk menurunkan tegangan ketika tegangan yang diperoleh melebihi batas yang ditentukan dan pada bagian boost berfungsi untuk menaikan tegangan ketika tegangan yang dibutuhkan kurang.

Menghitung besaran duty cycle pada mode ini menggunakan persamaan 4 .

$$
D=\frac{V_{o}}{V_{o}-V_{i}}
$$

Besarnya komponen L minimal dan $\mathrm{C}$ minimal dihitung berdasarkan persamaan 5 dan 6 .

$$
\begin{aligned}
& \operatorname{Lmin}=\frac{(1-D)^{2}}{2 * f} * R \\
& C=\frac{\cdot V o * D}{R * \Delta V o * f}
\end{aligned}
$$


Rangkaian buck boost converter ditunjukkan pada gambar 3.

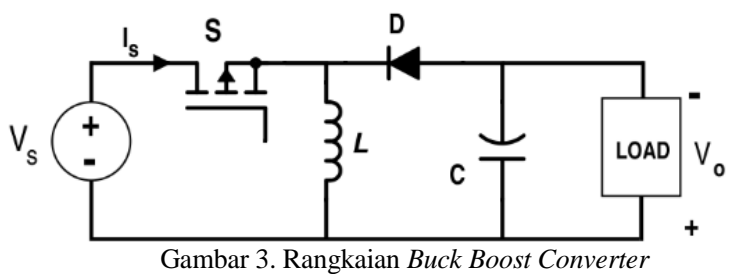

\section{Kontrol Fuzzy}

Kontroller logika fuzzy bertujuan untuk memantau seberapa besar kapasitas dari superkapasitor yang tersisa dan untuk menentukan keluaran dari superkapasitor. Kontrol fuzzy menggunakan 2 buah masukan yaitu SoC $\mathrm{SC}$ dan load demand (Pdem) dan 1 buah keluaran yaitu SC load (Psc).

Fungsi Keanggotaan SoC SC pada masukan kontrol fuzzy terdapat 3 membership function yang mana pada membership function memiliki batasan nilai yang berbeda sepertipada gambar 2, untuk fungsi low sendiri mempunyai batasan nilai dari $0-60$, dan medium mempunyai batasan dati 50 - 100 sedangkan fungsi high mempunyai batasan 95 - 100. Batasan tersebut merupakan nilai dari kapasitas superkapasitor.

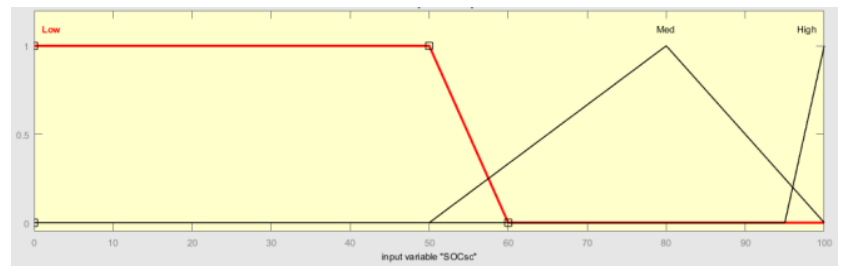

Gambar 4. Fungsi Keanggotaan Masukan SoC SC

Fungsi Pdem (Load Demand) sebagai nilai acuan berfungsi untuk menentukan seberapa besar nilai keluaran. Terdapat 5 fungsi keanggotaan pada Pdem, fungsi Vlow mempunyai batasan dari 0-3000, fungsi low 2000-5000,fungsi med 4000-7000, fungsi high 6000-9000, fungsi Vhigh 80001000. Batasan tersebut merupakan nilai seberapa besar daya permintaan yang di inginkan.

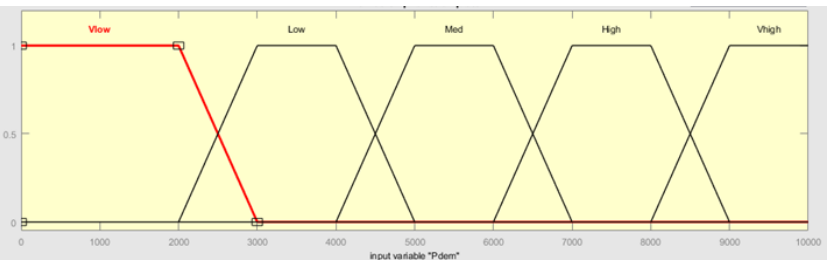

Gambar 5. Fungsi Keanggotaan Masukan Pdem

Keluaran (output) fuzzy adalah berupa permintaan daya pada superkapasitor (Psc) yang mana parameter keanggotaan pada keluaran kontrol fuzzy. Pada keluaran Fuzzy (Psc) terdapat 3 membership function yang berfungsi sebagai batasan nilai keluaran logika fuzzy yang akan masuk ke konverter superkapasitor, 3 fungsi tersebut adalah, low mempunyai batasan dari 0-5000, medium 2500-7500 dan high 5000-10000.

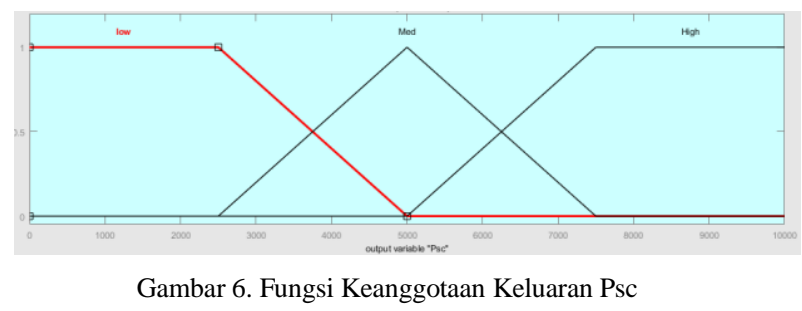

Aturan Fuzzy Logic Controller yang diterapkan pada sistem ditunjukkan pada tabel 1 .

Tabel 1. Aturan Fuzzy

\begin{tabular}{ccccccc}
\hline \multirow{2}{*}{ Psc } & & \multicolumn{5}{c}{ Pdem } \\
\cline { 4 - 7 } & & Vlow & Low & Med & High & Vhigh \\
\cline { 5 - 7 } & Low & Low & Low & Low & Med & High \\
SoCsc & Med & Low & Low & Med & High & High \\
& High & Low & Low & Med & High & High \\
\hline
\end{tabular}

\section{Power Management Strategy}

Power Management Strategy digunakan untuk memenuhi kebutuhan energi sesuai yang diinginkan. Power management yang dirancang berdasarkan pada baterai dan supercapasitor yang mana memiliki karakteristik yang berbeda.

Baterai dan superkapasitor berada pada posisi parallel yang mana gangguan (power distrubance) dapat dirasakan bersamaan pada baterai dan superkapasitor, keuntungan dari hubung parallel adalah baterai dapat dilindungi dari hubung pendek atau fluktuasi daya, pada saat fluktuasi daya superkapasitor merespon kelebihan dan kekurang daya sebagai masukan pada superkapasitor.

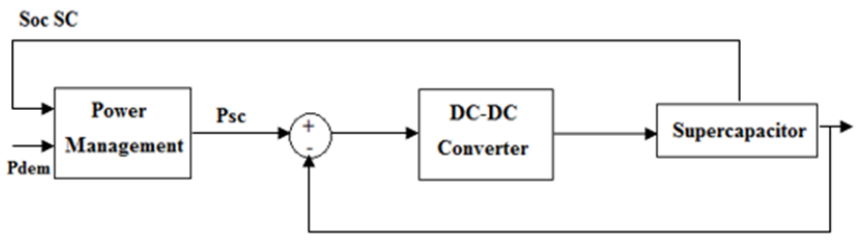

Gambar 7. Diagram Blok Power Management Strategy

Gambar 7 menunjukkan bahwa masukan dari blok Power Management ialah SoC SC dari superkapasitor dan daya permintaan Pdem. Keluaran dari blok Power Management adalah berupa sinyal daya refrensi Psc sebagai masukan konverter dengan mengurangi nilai arus refrensi dengan arus masukan yang dihasilkan oleh sensor yang ada pada superkapasitor, sinyal feedback yang dihasilkan dapat dirubah menjadi sinyal PWM yang dapat digunakan sebagai pensaklaran pada converter untuk menentukan converter akan berkerja pada buck atau buck boost.

\section{E. Model Daya Permintaan}

Daya permintaan yang digunakan merupakan indikasikan sebagai banyaknya energi yang dibutuhkan seperi ditunjukkan pada Gambar 6. Daya yang digunakan bervariasi sesuai gambar 8 . Daya yang tersusun akan aktif pada waktu (detik) tertentu. Beban akan aktif pada detik 0 hingga 1.2 yaitu sebesar 2500 hingga $7000 \mathrm{~W}$, detik 1.2 
sebesar $6000 \mathrm{~W}$, detik 1.6 hingga 2 sebesar 7500 hingga $9400 \mathrm{~W}$, detik 2.2 sebesar $7000 \mathrm{~W}$, detik 2.4 sebesar $8000 \mathrm{~W}$, detik 2.6 sebesar $5000 \mathrm{~W}$, detik 2.8 sebesar $9500 \mathrm{~W}$, detik 3 sebesar $4000 \mathrm{~W}$, detik 3.2 sebesar $8300 \mathrm{~W}$, detik 3.4 - 3.5 sebesar $9200 \mathrm{~W}$, detik 3.8 hingga 5 sebesar 8600 hingga $4000 \mathrm{~W}$.

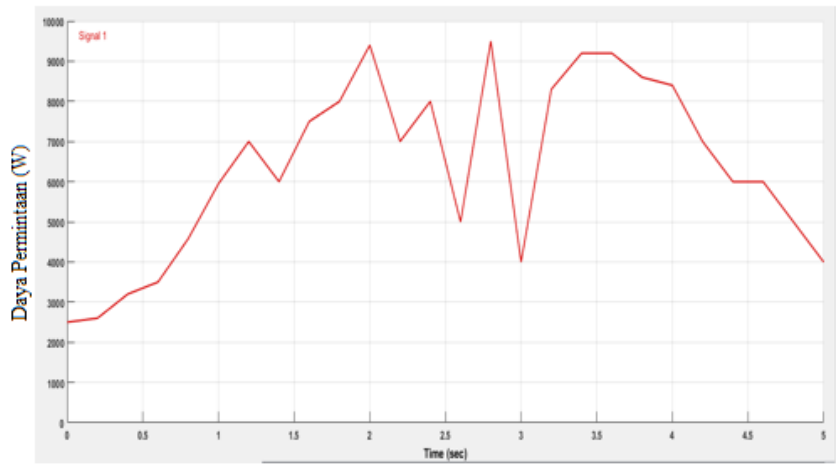

Gambar 8. Grafik Daya Permintaan

\section{HASIL DAN PEMBAHASAN}

\section{A. Pengujian $P V$}

Pengujian Photovoltaic dilakukan untuk mengetahui karakteristiknya, yaitu seberapa besar tegangan dan arus pada saat nilai inputan irradiance (Ir) dan temperature (T) yang berbeda - beda, yang mana dalam pengujian nanti akan dilakukan nilai inputan $\mathrm{T}$ yang berbeda - beda dan nilai inputan Ir yang sama. Hasil keluaran pada pengujian nilai Temperature yang berbeda dan nilai Radiasi yang sama terlihat pada gambar 9 terlihat semakin kecil nilai temperature, nilai tegangan semakin tinggi dengan radiasi $1000 \mathrm{~W} / \mathrm{m}^{2}$.

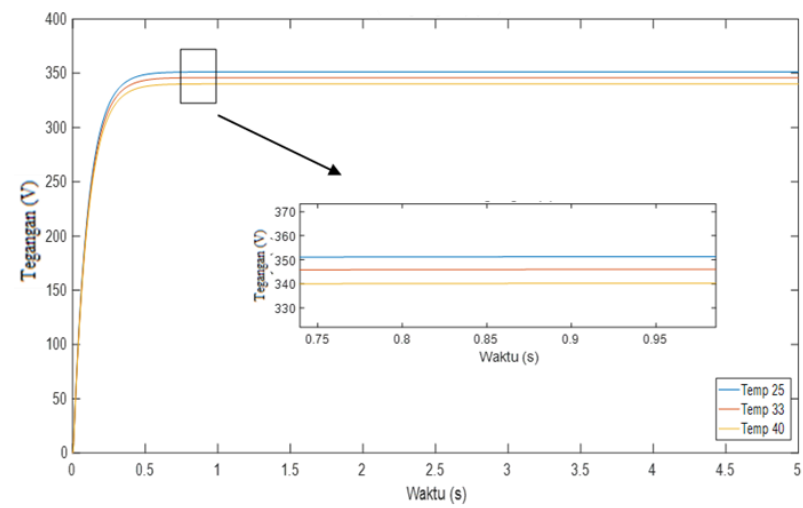

Gambar 9. Tegangan PV saat T (beda) Ir (sama)

\section{B. Pengujian Power Management pada sistem baterai dan supercapasitor.}

Hasil simulasi pengujian daya permintaan beban terhadap baterai dan superkapasitor ditunjukkan pada gambar 10. Pada gambar tersebut terlihat baterai dan superkapasitor mampu memenuhi daya permintaan beban yang mana keluaran daya pada baterai dan superkapasitor mampu memenuhi setiap daya yang dibutuhkan. Pada detik $<1.5 \mathrm{~s}$ terlihat respon yang lambat membuat daya permintaan tidak terpenuhi, tetapi pada detik selanjutnya baterai dan superkapasitor mampu memenuhi daya permintaan yang diberikan. Perbedaan hasil keluaran terlihat pada gambar, dimana selisih daya yang dihasilkan oleh baterai dan superkapasitor pada detik 2.85 adalah $9324 \mathrm{~W}$ sedangkan daya permintaan $8130 \mathrm{~W}$, yang mana baterai dan superkapasitor mampu memenuhi daya permintaan dengan selisih daya sebesar 1194W.

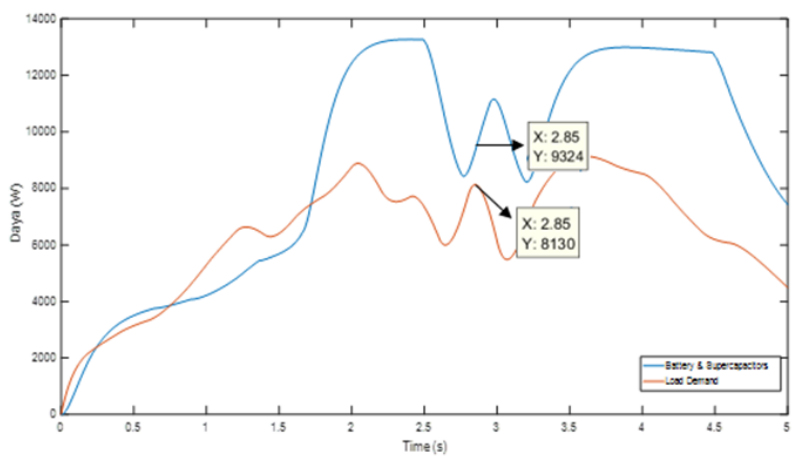

Gambar 10. Keluaran daya Baterai dan Superkapasitor Terhadap Daya Permintaan

\section{Simulasi Respon Supercapacitors dan Battery}

Pada gambar 11 menunjukan respon superkapasitor pada baterai pada saat terjadi lonjakan daya permintaan pada detik ke 2.93s. Pada detik tersebut superkapasitor mampu mensuplai energi ketika lonjakan daya terjadi. Selisih daya yang dihasilkan pada detik tersebut adalah $1158 \mathrm{~W}$.

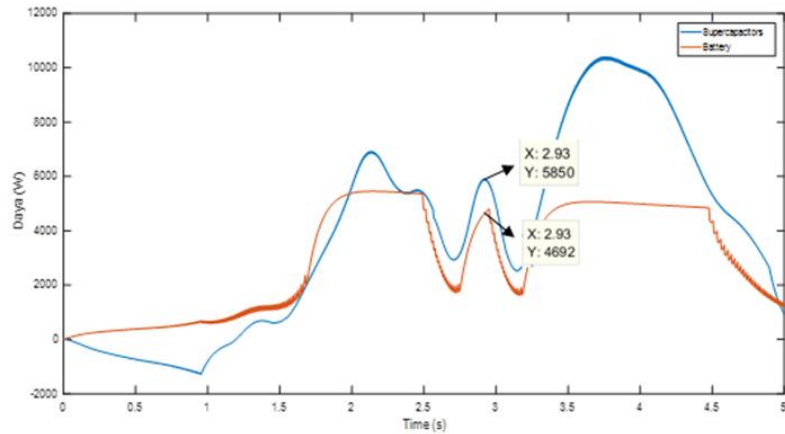

Gambar 11. Hasil Simulasi Supercapacitors dan Battery

\section{Simulasi Respon Buck-Boost Converter}

Hasil respon keluaran konverter berupa besaran arus dan tegangan yang terdapat pada rangkaian superkapasitor . masukan daya pada konverter adalah hasil dari keluaran fuzzy maka didapat nilai arus dan tegangan pada gambar 12. Nilai tegangan yang dihasilkan menunjukan cenderung stabil dan untuk nilai arus yang dihasilkan mengalami perubahan yang berubah - ubah mengikuti pola daya permintaan 


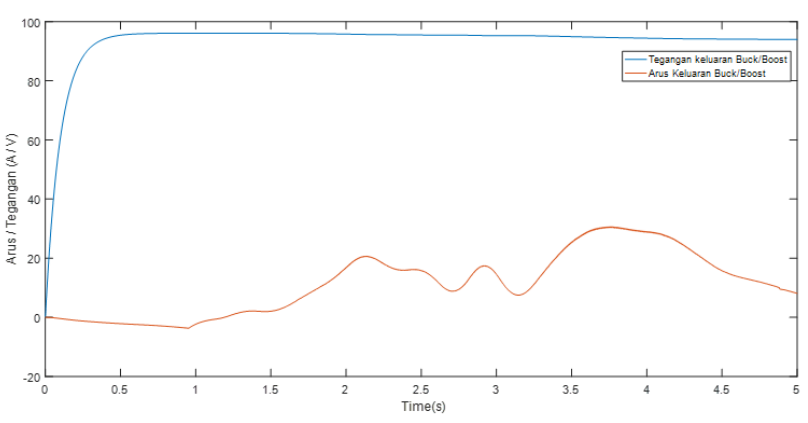

Gambar 12. Respon Arus/Tegangan Konverter Buck-Boost

\section{E. Simulasi Respon Boost Converter}

Gambar 13 memperlihatkan hasil respon keluaran boost konverter. Terlihat bahwa tegangan berubah - ubah mengikuti pola daya permintaan membuktikan bahwa baterai mampu mengikuti pola daya yang di inginkan pada grafik daya permintaan, sedangkan pada keluaran arus baterai terlihat nilai arus juga mengalami fluktuasi.

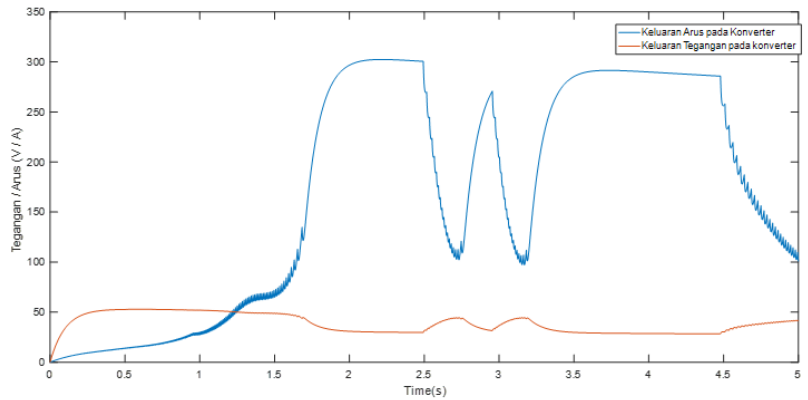

Gambar 13. Respon Arus/Tegangan Konverter Buck-Boost

\section{KESIMPULAN}

Hasil pengujian photovoltaic saat nilai radiasi tetap pada nilai 1000 dan nilai suhu berubah - ubah dari 25,33 dan 40 maka tengangan akan menurun mengikuti perubahan suhu. Hal ini terjadi dikarenakan semakin tinggi nilai dari Temperature, maka nilai effisiensi PV akan menurun. Pada saat nilai suhu tetap dan nilai radiasi berubah - ubah dari 1000, 800,500 maka akan mempengaruhi keluaran tegangan pada PV, jadi semakin tinggi nilai irradiance maka semakin tinggi juga nilai keluaran tegangan pada PV. Sehingga semakin tinggi nilai irradiance maka semakin besar juga nilai keluaran tegangan dibandingkan semakin tinggi nilai temperature yang akan membuat effisiensi PV akan menurun. Battery dan Supercapacitors pada saat terjadi lonjakan daya permintaan pada detik ke $2.93 \mathrm{~s}$, pada detik tersebut superkapasitor mampu mensuplai energi ketika lonjakan daya terjadi. Selisih daya yang dihasilkan pada detik tersebut adalah 1158 W. Power Management system mampu mengontrol keluaran baterai dan superkapasitor untuk memenuhi daya permintaan yang dibutuhkan, terlihat pada detik $<1,7$ s terlihat respon yang lambat membuat daya permintaan tidak terpenuhi disebabkan karena proses perhitungan algoritma logika fuzzy.

\section{REFERENSI}

[1] Hongwei Wu, Fabrice Locment, Manuela Sechilariu Changjie Yin, "Energy management of DC microgrid based on photovoltaic combined," Energy Conversion and Management, pp. 14-27, 2017.

[2] Tao Zhou and Bruno François, "Energy Management and Power Control of a Hybrid Active Wind Generator for Distributed Power Generation and Grid Integration ," IEEE TRANSACTIONS ON INDUSTRIAL ELECTRONICS, vol. 58, pp. 95-104, january 2011.

[3] Machmud dkk, "Implementasi Maximum Power Point Tracking pada Photovoltaic Berbasis P\&O-Fuzzy", JNTETI Vol.6 No.1 2017

[4] Jianwei Li, "A SC/battery Hybrid Energy Storage System in the Microgrid ," Energy Procedia, vol. 142, no. Microgrid, pp. 3697. 3702, 2017

[5] Zineb Cabrane, "Battery and supercapacitor for photovoltaic energy storage: a fuzzy logic management," IET Renewable Power Generation, vol. 11, no. 8, pp. 1157-1165, june 2017.

[6] Tanmay Rout and Ankit Chowdhury, "Analysis of Energy Management System for," IEEE International Conference on Technologies for Smart-City Energy Security and Power (ICSESP2018), March 2018.

[7] Manuela Sechilariu, "Supervision control for optimal energy cost management," Electrical Power and Energy Systems, vol. 58, pp. 140-149, january 2014

[8] Farid Miharja, "Perencanaan Dan Manajemen Pembangkit Listrik Tenaga Hybrid (Angin/Surya/Fuel Cell) Pulau sumba menggunakan Software Homer," Teknik Elektro ITS, 2014.

[9] Firmansyah Putra Pratama, "Sistem Pembangkit Listrik Hibrida PVDiesel Microgrid Untuk Daerah Terisolasi Tanpa Menggunakan Media Penyimpan Energi," Jurnal Teknk POMITS, vol. 1, pp. 1-5, 2012.

[10] Zainal Salam, "Power Electronics and Drives ," vol. 3, pp. 1-20, 2003.

[11] Muhammad Rashid, "POWER ELECTRONICS HANDBOOK," DC-DC Converters, pp. 213-215, 2001. 